\title{
O ASPECTO ICÔNICO DA LINGUAGEM VISUAL
}

\section{THE ICONIC ASPECT OF VISUAL LANGUAGE}

\author{
Fábio Rogério Batista Limaa \\ Plácida Leopoldina Ventura Amorim da Costa Santos ${ }^{b}$
}

\begin{abstract}
RESUMO
Introdução: A percepção das informações nos signos imagéticos, representadas em diversas formas e suportes, como por exemplo: nas fotografias, nas pinturas e nos diagramas, estão repletas de informações implícitas e explícitas. Uma fotografia, por exemplo, representa um objeto, pessoa ou lugar existente, ou algum momento histórico, ao mesmo tempo em que contém informações físicas de sua própria materialidade. Objetivo: Traçar uma relação entre a Semiótica de Charles Sanders Peirce e o estudo da forma, utilizada no livro 'Sintaxe da Linguagem Visual'. Metodologia: O estudo é de caráter teórico, de nível descritivo e exploratório e teve como base a observação sistemática qualitativa da bibliografia coletada sobre a temática da Semiótica de Charles Sanders Peirce. Resultados: Foi apresentado o conceito de ícone e suas variáveis, bem como, traçou-se uma relação do signo icônico com o estudo dos elementos visuais. Conclusões: A comunicação visual, especialmente atrelada à linguagem imagética, relaciona-se em seus aspectos sintáticos e semânticos com o estudo da Semiótica. É de suma importância o alfabetismo visual como um método facilitador de extração de informações sígnicas contidas nas sintaxes visuais, mais especificamente nas imagens.
\end{abstract}

Descritores: Princípios do alfabetismo visual. Sintaxe da imagem. Ícone. Semiótica.

\section{INTRODUÇÃO}

O saber é constituído, dentre outros aspectos, pela face pragmática, ou seja, ser prático e ter objetivos definidos, pela face semiológica ou Semiótica relativa ao significante - e, a face epistemológica - referente ao significado das palavras.

O estudo semiótico tem por objetivo investigar todas as linguagens possíveis, como a linguagem oral (através da fala), a linguagem textual (através

\footnotetext{
a Doutor pelo Programa de Pós-Graduação em Ciência da Informação, Universidade Estadual Paulista (Unesp). Docente no curso de Aprendizagem Profissional do SENAC - Serviço Nacional de Aprendizagem Profissional, Marília-SP. E-mail: fabio.robal@yahoo.com.br

b Docente do Programa de Pós-Graduação em Ciência da Informação da Universidade Estadual Paulista Júlio de Mesquita Filho (Unesp). E-mail: placida@marilia.unesp.br
} 
de textos), a linguagem corporal (através de gestos), a linguagem visual (através de imagens), dentre outros. Pois, "[...] examina os modos de constituição de todo e qualquer fenômeno de produção de significação e sentido." (SANTAELLA, 1983, p. 13).

Neste sentido, a comunicação e as trocas de informações através de códigos visuais por meio de imagem ainda são utilizadas nos dias de hoje. Pois, desde o princípio, o ser humano tem a necessidade de se comunicar com os seus semelhantes e os meios utilizados para esse processo têm variado ao longo dos séculos.

A linguagem, definida como a produção e entendimento da fala, se desenvolveu com a evolução da espécie humana. A fala humana poderia ser comparada à comunicação entre outros animais, porém, a linguagem humana tem elementos que a distingue da linguagem dos animais, na medida em que possui a criatividade e interpretação.

No início, quando os parentes Homo Herectus (que viveram entre 1,8 milhões de anos e 300.000 anos atrás) habitavam a Terra, o centro de sua fala não era muito desenvolvido, pois a comunicação se dava por meio de grunhidos, rosnadas e gestos. Na época dos Neandertais (há cerca de 300.000 anos até aproximadamente 29.000 anos atrás), acredita-se que o hemisfério esquerdo do cérebro desenvolveu-se um pouco mais. Com os Homo Sapiens (há 200.000 anos), o cérebro se desenvolveu propiciando a produção da fala, período assim caracterizado pela linguagem. Nesse caso, o papel da linguagem é primordial, pois "[...] ela garante o intercâmbio da significação, mediando as relações entre pessoas, flexibilizando o pensamento e ampliando a capacidade conceitual e proposicional de cada indivíduo." (BARRETO, 2008, p. 114).

Percebemos que as imagens hoje estão em todos os lugares: em placas de trânsito, outdoors, vitrines, bancas de jornal, logomarcas de empresas ou em livros, revistas e, massivamente, na rede Internet. De acordo com Aumont (1993, p. 314) "As imagens, isso é inegável, há mais de 100 anos multiplicam-se quantitativamente em proporções impressionantes e sempre crescentes."

Nos signos icônicos, ou seja, os signos que agem como tal em função de uma relação de semelhança com seu objeto puramente no nível da aparência, 
tais como as imagens, diagramas, metáforas, os quais são representados em diversas formas e suportes, como por exemplo nas fotografias e nas pinturas.

Esses signos estão repletos de informações implícitas e explícitas. Uma fotografia, por exemplo, representa um objeto, pessoa ou lugar existente, ou algum momento histórico, ao mesmo tempo em que contém informações físicas de sua própria materialidade.

Dessa forma, partimos da problemática de que estamos repletos de Linguagens Visuais ao nosso redor as quais crescem exponencialmente. No entanto, precisa-se de um método para ensinar a leitura desses recursos para os profissionais da informação no que diz respeito às suas unidades estruturais elementares. Esse conhecimento servirá como uma ferramenta facilitadora da análise e representação de recursos dessa natureza, pois, cada vez mais estamos nos deparando com informações advindas de recursos visuais sob diversos tipos de fontes e unidades de informação. Para isso, objetivamos traçar uma relação entre a Semiótica de Charles Sanders Peirce e os princípios do alfabetismo visual, embasado no livro 'Sintaxe da Linguagem Visual' da autora Donis A. Dondis no que se refere a unidades mínimas de informação em relação à imagem.

O estudo é de caráter teórico, pois "[...] tem como objetivo ampliar generalizações, definir leis mais amplas, estruturar sistemas e modelos teóricos, relacionar e enfaixar hipóteses numa visão mais unitária do universo e gerar novas hipóteses por força de dedução lógica" (OLIVEIRA, 1997, p. 123). De nível descritivo, por "[...] possibilitar as explicações das relações de causa e efeito dos fenômenos, ou seja, analisar o papel das variáveis que, de certa maneira, influenciam ou causam o aparecimento dos fenômenos" (OLIVEIRA, 1997, p. 123). E exploratório, na medida em que "[...] possibilita ao pesquisador fazer um levantamento provisório do fenômeno que deseja estudar de forma mais detalhada e estruturada, além da obtenção de informações acerca de um determinado produto" (OLIVEIRA, 1997, p. 135).

A pesquisa apresenta abordagem qualitativa, tendo como base a observação sistemática da bibliografia coletada, utilizando o suporte teórico da Ciência da Informação nas reflexões sobre a temática da Semiótica de Charles 
Sanders Peirce aplicada ao universo imagético.

\title{
Semiótica
}

A Semiótica (do grego semeiotiké) é a ciência que estuda o processo de articulação e produção de sentido entre os diversos tipos de códigos e linguagens. Tem por objetivo "[...] estabelecer como deve ser todos os signos para uma inteligência capaz de apreender através da experiência [...]" (SILVEIRA, 2007, p. 38). Ocupa-se do estudo do processo de significação ou representação, na natureza e na cultura dos conceitos e das ideias.

Em uma acepção geral a "[...] Semiótica é a teoria de todos os tipos de signos, códigos, sinais e linguagens. Portanto, ela nos permite compreender palavras, imagens, sons em todas as suas dimensões e tipos de manifestações" (SANTAELA, 2010, p. 59). As linguagens estão no mundo e nós fazemos parte delas. Segundo Nöth (2008, p. 21),

\begin{abstract}
A Semiótica como teoria geral dos signos teve várias denominações no decorrer da história da filosofia. A etimologia do termo nos remete ao grego semeîon, que significa signo, e sema, que pode ser traduzido por "sinal" ou também "signo". Semio-, uma transliteração latinizada da forma grega semeio-, e os radicais parentes, sema(t)- e seman-, têm sido a base morfológica para várias derivações de vocábulos que dão nome às ciências Semióticas.
\end{abstract}

De acordo com Nöth (2008, p. 18), "[...] a Semiótica propriamente dita tem sua origem com filósofos como John Locke (1632-1704) que, no seu Essay on human understanding, de 1690, postulou uma 'doutrina dos signos' com o nome de Semeiotiké [...]" ou supostamente, com o trabalho do filósofo Johann Heinrich (1728-1777), o qual escreveu um tratado específico intitulado Semiotik.

No entanto, Peirce (1990) atribui o nome Semiótica ao filósofo inglês John Locke que afirmava que todas as nossas ideias tinham origem no que era percebido pelos sentidos. Segundo Locke "Semiótica é a doutrina dos signos, que se ocupa da relação triádica entre sinais ou representação da coisa, a coisa propriamente dita e as ideias. Outro nome para Semiótica seria lógica." (LOCKE, 1988, p. 211).

Afirma Nöth $(2008$, p. 18) que, a doutrina dos signos, que segundo ele "compreende todas as investigações sobre a natureza dos signos, da 
significação e da comunicação na história da ciência" coincide com a história da filosofia, uma vez que Platão e Aristóteles eram teóricos do signo e, portanto semioticistas. Entretanto, somente no final do século XIX, início do século XX, com trabalhos paralelos, sendo realizados na Europa e nos Estados Unidos de forma independente pelo linguista Ferdinand de Saussure (1857-1913) e o semiólogo Charles Sanders Peirce (1839-1914) com a - fenomenologia -, a Semiótica consolida-se e começa a adquirir autonomia e status de ciência.

Tudo o que vemos, sentimos e ouvimos remete aos nossos sentidos, noções do que é real, e para que percebamos o quão vivo e interativo nós estamos com a realidade que nos cerca, e interagirmos com essa realidade e com os seres que nela vivem, sentimos necessidades, como seres sociais que somos, de nos comunicarmos.

Na comunicação, fazemos uso de diversos tipos de linguagens sígnicas algumas delas classificadas por Peirce de ícones, índices e símbolos, e são explicadas da seguinte forma:

\begin{abstract}
Um signo é um ícone, um índice ou um símbolo. Um ícone é um signo que possuiria o caráter que o torna significante, mesmo que seu objeto não existisse, tal como um risco feito a lápis representando uma linha geométrica. Um índice é um signo que de repente perderia seu caráter que o torna um signo se seu objeto fosse removido, mas que não perderia esse caráter se não houvesse interpretante. Tal é, por exemplo, o caso de um molde com um buraco de bala como signo de um tiro, pois sem o tiro não teria havido buraco ; porém, nele existe um buraco, quer tenha alguém ou não a capacidade de atribuí-lo a um tiro. Um símbolo é um signo que perderia o caráter que o torna um signo se não houvesse um interpretante. Tal é o caso de qualquer elocução de discurso que significa aquilo que significa apenas por força de compreender-se que possui essa significação (PEIRCE, 1990, p. 74).
\end{abstract}

A Semiótica de Charles Sanders Peirce foi estruturada de forma triádica. Peirce classificou o pensamento em relações de tríades. A primeira Tricotomia diz respeito ao signo em relação a ele próprio. Indica que com respeito a sua própria constituição, "caráter de apresentação" (CP, 2. 243), um signo pode ser uma qualidade (Quali-sino), um existente (Sin-sígno) ou uma lei (Legi-sígno). Ou seja, para Peirce, entre as infinitas propriedades materiais, substanciais, etc que as coisas tem, há três propriedades que a faz funcionar como signo: sua mera 
qualidade, seu simples fato de existir e seu caráter de lei.

Na segunda Tricotomia, indica o 'caráter interpretativo' do signo (CP, 2.243). Um signo pode ser um Ícone, um Índice ou um Símbolo. Já na terceira Tricotomia indica como o signo se apresenta para seu interpretante. Indica o "poder interpretativo" do signo (CP, 2.243). Descreve o poder do signo para produzir interpretantes.

Pelo fato dos processos semióticos funcionarem de forma dinâmica, uma coisa pode ser classificada, por exemplo, como ícone, índice ou símbolo, etc. No entanto, dependerá de fatores como o contexto e as relações em que se dá a semiose. Ou seja, "o processo no qual o signo tem um efeito cognitivo sobre o intérprete" (CP, 5.484). O processo de semiose é um processo vivo. Portanto, para utilizarmos as classificações de Peirce, devemos levar em conta que esse sistema só funciona de acordo com um fundamento e uma perspectiva de interpretação e dependerá de como ela se relaciona com um conjunto maior de anunciados, que é nossa comunicação.

A relação e compreensão desses signos, de alguma maneira, agregam em nossas faculdades cognitivas algum tipo de juízo. Seja de maneira superficial, fornecendo informações, ou de maneira mais profunda, agregandonos conhecimento.

Pensa-se semioticamente a informação, partindo do pressuposto de que todo e qualquer sistema que gera significados estruturados a partir de fluxos informacionais estão diretamente ligados através de signos nas três categorias tricotômicas já mencionadas, as quais para Peirce são as três categorias da experiência: Primeiridade, Secundidade e Terceiridade.

Na definição de Peirce, "[...] primeiridade é o modo de ser daquilo que é tal como é, positivamente e sem referência a outra coisa qualquer" (CP, 8.328). É a categoria do sentimento sem reflexão, da mera possibilidade, da liberdade, do imediato, da qualidade ainda não distinguida e da independência (CP, 1.302$303,1.328,1.531$ ).

A primeiridade seria uma instância da experiência que se refere aos aspectos qualitativos, meramente sensacionais e/ou sensoriais do objeto, contanto que experimentados de maneira absolutamente não reflexiva, não 
pensada. Na medida em que se percebe a sensação, a qualidade, ou se presta atenção no objeto tal como ele se forma em nossa mente, estaremos atentando para a sua alteridade.

Para Peirce, a "Secundidade começa quando um fenômeno primeiro é relacionado a um segundo fenômeno qualquer" (CP, 1.356-359). Em outras palavras, estaremos tendo, com o objeto, uma relação diádica, ou binária. Estaremos percebendo o objeto como um outro, um segundo, um ele e, portanto, como algo já dado. Daí dizermos que essa experiência do outro estaria na ordem da secundidade.

A Terceiridade, segundo Peirce, "[...] é a categoria que relaciona um fenômeno segundo a um terceiro" (CP, 1.337/ss): "É a categoria da mediação, do hábito, da memória, da continuidade, da síntese, da comunicação, da representação, da semiose e dos signos". Corresponde à camada de inteligibilidade, ou pensamento em signos, através da qual representamos e interpretamos o mundo. Dessa forma, "[...] de acordo com a ciência cognitiva tradicional, as representações desempenham um duplo papel: carregam um conteúdo e causam o comportamento" (HASELAGER, 2004, p. 106). A utilidade das representações é o fato de ocuparem lugar de algo ausente no ambiente.

Para facilitar a compreensão dos signos apresentaremos como tais se relacionam com seus respectivos "objetos", os quais Peirce diz que podem ser "[...] uma coisa material do mundo, do qual temos um conhecimento perceptivo [...]" (CP, 2.230), mas também podem ser uma entidade meramente mental ou imaginária "[...] da natureza de um signo ou pensamento" (CP, 1.538). Peirce reconheceu duas espécies de objeto: Objeto Imediato e Objeto Mediato, Real ou Dinâmico.

O Objeto Imediato é o "objeto dentro do signo", o objeto "como o signo mesmo o representa e cujo ser depende, portanto, da representação dele no signo" (CP, 4.536). O objeto Mediato, Real ou Dinâmico é "o objeto fora do signo" é a "realidade que, de certa maneira, realiza a atribuição do signo à sua representação" (CP, 4.536).

Segundo Nöth (2008, p. 68), "[...] esse segmento da realidade, também chamado objeto real, é imediato e dinâmico porque só pode ser indicado no 
processo da semiose". O Objeto Dinâmico é, portanto, "aquilo que são as naturezas das coisas, o signo não pode exprimir e só pode indicar, deixando para o intérprete descobrí-lo por experiência colateral” (CP, 8.314).

Segundo Santaella (2010, p. 15),

Quando olhamos para uma fotografia, lá se apresenta uma imagem. Essa imagem é o signo e o objeto dinâmico é aquilo que a foto capturou no ato da tomada a que a imagem na foto corresponde [...]. O modo como o signo representa, indica, se assemelha, sugere, evoca aquilo a que ele se refere é o objeto imediato.

Dessa forma, o objeto imediato de um ícone só poderá evocar ou sugerir seu objeto dinâmico. Trataremos de questões relacionadas ao ícone no próximo tópico.

\section{PROPRIEDADES DO ÍCONE}

Antes de tratarmos das propriedades do ícone, falaremos primeiramente o que é denominado signo. Peirce refere-se ao signo toda e qualquer coisa com capacidade de significar algo para alguém.

Segundo Peirce (1990, p. 64),

Um Signo, ou Representâmen, é um Primeiro que se coloca em relação triádica genuína tal com um segundo, denominado seu Objeto, que é capaz de determinar um terceiro, denominado seu Interpretante, que assuma a mesma relação triádica com seu Objeto na qual ele próprio está em relação com o mesmo Objeto.

Dessa forma, qualquer coisa para Pierce pode ser considerada um signo, como por exemplo uma frase, um objeto, um som, uma imagem, um sentimento, dentre muitas outras coisas. Todas essas entidades tanto materiais, quanto substanciais possuem três propriedades formais que as tornam capazes de funcionar como signo: sua mera qualidade, sua existência (simples fato de existir) ou seu caráter de lei. Por esses fatos, tudo pode ser considerado, segundo Peirce 1990, signo.

Trataremos agora de um signo que tem como fundamento uma qualidade, chamado por Peirce (1990, p. 64) de ícone.

Um Ícone é um Representâmen cuja qualidade representativa é sua primeiridade como primeiro. Ou seja, a qualidade que ele tem qua coisa o torna apto a ser um representâmen. Assim, 
qualquer coisa é capaz de ser um substituto para qualquer coisa com a qual se assemelha.

O ícone por ser um signo cuja sua qualidade significante provém meramente de sua qualidade, ele faz parte da primeiridade. Dessa forma, o ícone é ao mesmo tempo um quali-signo, mas um quali-signo icônico, também classificado de ícone puro, o qual participa fundamentalmente da categoria de primeiridade, sendo apenas uma possibilidade hipotética da existência de um signo, "[...] o signo genuíno participa necessariamente das categorias da secundidade (qua objeto) e da terceiridade (qua interpretante)" (NÖTH, 2008, p. 78).

Entende-se por ícone puro, um signo não comunicável, pois,

O ícone puro é independente de qualquer finalidade, serve só e simplesmente como signo pelo fato de ter a qualidade que o faz significar". Assim entendido, o ícone puro não pode verdadeiramente existir; pode, no máximo, constituir "um fragmento de um signo mais completo". Peirce também define a ideia de um ícone puro como sendo um caso de "degeneração semiótica". Um ícone puro seria, pois, um signo degenerado não no sentido de uma avaliação pejorativa - mas no sentido de estar restrito a participar de apenas um constituinte do signo (NÖTH, 2008, p. 78-79).

Em contraposição ao ícone puro, Peirce também se referiu aos ícones que participam na secundidade e na terceiridade, denominando-os hipo-ícones. "Um hipo-ícone é um sin-signo icônico ou um legi-signo-icônico" (NÖTH, 2008, p. 79).

Os hipoícones, segundo Peirce (1990, p. 64),

Podem ser divididos de acordo com o modo de primeiridade de que participem. Os que participam das qualidades simples, ou primeira primeiridade, são imagens; os que representam as relações, principalmente as diádicas, ou as que são assim consideradas, das partes de uma coisa através de relações análogas em suas próprias partes, são diagramas; os que representam o caráter representativo de um representâmen através da representação de um paralelismo com alguma outra coisa são metáforas.

Ou seja, Peirce fez a divisão dos signos icônicos, os quais agem em função de semelhança com seus objetos, em três níveis: imagem, diagrama e metáfora. Segundo Santaella (2010, p. 18)

A imagem estabelece uma relação de semelhança com seu objeto puramente no nível da aparência. Imagens de um gato, 
de um bosque, de uma praça podem representar esses objetos quando apresentam níveis de similaridade com o modo como os mesmos são visualmente percebidos. O diagrama representa seu objeto por similaridade entre as relações internas que o signo exibe e as relações internas do objeto que o signo visa representar [...]. A metáfora representa seu objeto por similaridade no significado do representante e do representado.

Há três categorias para distinguir três modos de primeiridade dos ícones: No primeiro caso, o representâmen do ícone é signo por mera qualidade e tem o nome de imagem. O autor nos dá exemplo do valor de apresentação da cor em uma pintura, a exemplo das pinturas monocromáticas a qual é um caso típico de ícone do tipo imagem.

No segundo caso, o representâmen é ícone devido às relações diádicas existentes entre suas próprias partes, como acontece em um diagrama [...] (NÖTH, 2008, p. 79). Contudo, "[...] muitos diagramas não se assemelham de modo algum aos seus objetos quanto à aparência; a semelhança entre eles consiste apenas na relação entre suas partes" (CP, 2.282).

No terceiro caso, o representâmen é signo porque mantém relações triádicas na forma de paralelismo entre dois elementos constitutivos, paralelismo que se resolve com uma terceira relação (NÖTH, 2008, p. 79).

Ao considerarmos somente o lado qualitativo do signo, ou seja, somente seu caráter de qualidade (hipoícone), enfatizamos, apenas sua qualidade de aparência, sendo que qualidades de aparência podem se assemelhar a outras qualidades do mesmo caráter. É por isso que sendo em si mesmo um qualisigno, o signo em relação com o seu objeto se torna um ícone, ou melhor dizendo um hipoícone de primeiridade.

O ícone representa o objeto por meio de qualidades que ele próprio possui, existindo ou não este objeto. Ou seja, os ícones possuem um poder sugestivo pelo fato de não dependerem dos objetos externos (que estão fora deles). "Daí que, no universo das qualidades, as semelhanças proliferem" (SANTAELLA, 2010, p. 125).

A mesma autora nos dá alguns exemplos ilustrativos de quali-signo, como por exemplo, uma cor azul. O que dá poder a essa cor para funcionar como um signo é tão só e apenas sua qualidade. Na relação com objeto que o quali-signo 
pode porventura sugerir ou evocar. "[...] quali-signo é icônico, quer dizer é icônico porque o quali-signo só pode sugerir seu objeto por similaridade." Ícones são quali-signos que se reportam a seus objetos por similaridades. Ou seja,

\begin{abstract}
Quando a cor azul-clara lembra o céu ou os olhos azuis límpidos de uma criança, ela só pode lembrá-los porque há uma semelhança na qualidade desse azul com o azul do céu ou dos olhos. O ícone só pode sugerir ou evocar algo porque a qualidade que ele existe se assemelha a uma outra qualidade. Pensemos em mais um exemplo: manchas de tinta com formas completamente casuais em um papel. Retendo só a qualidade dessas formas, as formas nelas mesmas, independentemente de qualquer outra coisa, a aparência que as formas exibem cumpre ao mesmo tempo a função de fundamento, o quali-signo, e de objeto imediato. Não há nada nelas que possa representar qualquer outra coisa. São simplesmente manchas que se apresentam a si mesmas (SANTAELLA, 2010, p. 17).
\end{abstract}

Peirce (1990) usa dois exemplos para ilustrar quali-signo icônico, o primeiro exemplo é a fotografia, especialmente as do tipo "instantâneo". Segundo ele, as fotografias são muito instrutivas, pois, sabemos que, sob certos aspectos, são exatamente como os objetos que representam. Esta semelhança, no entanto, deve-se ao fato de corresponderem ponto a ponto à natureza.

Outro exemplo do uso de semelhança é a de um artista que produz uma estátua, uma composição pictórica, uma construção arquitetônica ou uma peça de decoração, "[...] através de cuja contemplação ele pode assegurar-se se aquilo que ele está propondo será bonito ou satisfatório" (PEIRCE, 1990, p. 65).

No entanto, ainda sobre os exemplos acima, quando contemplamos uma pintura, por exemplo, existe um momento em que perdemos a consciência do fato de que ela não é a coisa. A distinção do real e da cópia desaparece e por alguns momentos é puro sonho [...]; "Nesse momento estamos contemplando um ícone" (CP, 3.362). Contudo, segundo Santaella (2001, p. 199) "[...] todo índice envolvem ícones, mas não são os ícones que os fazem funcionar como signos. Esse ícone, no entanto, não precisa, necessariamente ser uma imagem do objeto."

Contudo, há o lado indicial da imagem, como nas fotografias, por exemplo, a qual caracteriza-se como índice genuíno, pois "[...] a conexão entre a imagem fotográfica e o objeto fotografado é física, dinâmica, existencial" (SANTAELLA, 2001, p. 199). 
Como Formas figurativas, o índice pode ser identificado em três modalidades: como qualidade; como registro; como convenção e, o que dá fundamento é sua existência concreta. Para indicar uma igreja barroca, por exemplo, a foto evidentemente precisa ser um existente tanto quanto a igreja registrada. Segundo Santaella (2010, p. 19), “[...] no caso do ícone, não há distinção entre o fundamento e o objeto imediato, já no caso do índice essa distinção é importante." Dessa forma, para ilustrara a relação do ícone com o índice, pensamos na imagem da igreja barroca, que se apresenta na foto, ela tem alguma semelhança com a aparência da própria igreja barroca, nesse aspecto, age como ícone dela, mas a imagem funciona como índice da igreja, na medida em que é resultado de uma conexão de fato entre a tomada da foto e a igreja.

No próximo tópico, trataremos do aspecto icônico da imagem e o poder representacional que ela possui.

\section{O SIGNO ICÔNICO E AS FORMAS REPRESENTATIVAS DA IMAGEM}

As imagens, atualmente, são instrumentos cada vez mais utilizados para representar informação e gerir conhecimento nos mais variados tipos de ambientes. Dessa forma, a imagem cumprindo sua função de registrar o imaginário, de significar e de dar sentido no mundo, "tem sido usada como meio e registro de conhecimento" (PLAZA, 1993, p. 72).

O quadro 1 ilustra a evolução da imagem ao longo do tempo, e o efeito que ela exerce sobre a sociedade e a cultura a que pertence.

Quadro 1 - Natureza da imagem, papel do receptor

\begin{tabular}{|l|l|l|}
\hline \multicolumn{3}{|c|}{ NATUREZA DA IMAGEM } \\
\hline \multicolumn{1}{|c|}{ PRÉ } & \multicolumn{1}{|c|}{ FOTOGRÁFICA } & \multicolumn{1}{c|}{ PÓS } \\
\hline $\begin{array}{l}\text { Figurar o visível e o } \\
\text { invisível }\end{array}$ & Registrar o visível & Visualizar o modelável \\
\hline Figurar por imitação & Capturar por conexão & $\begin{array}{l}\text { Simular por variações } \\
\text { de parâmetros }\end{array}$ \\
\hline Imagem espelho & Imagem documento & Imagem matriz \\
\hline \multicolumn{3}{|c|}{ PAPEL DO RECEPTOR } \\
\hline \multicolumn{1}{|c|}{ PRÉ } & FOTOGRÁFICA & PÓS \\
\hline
\end{tabular}




\begin{tabular}{|l|l|l|}
\hline Contemplação & Observação & Interação \\
\hline Nostalgia & Reconhecimento & Imersão \\
\hline Aura & Identificação & Navegação \\
\hline
\end{tabular}

Fonte: Santaella (2001, p. 172-178).

Nenhum processo de signo dispensa os meios nos quais eles foram produzidos, armazenados e transmitidos. Pois,

São esses meios que tornam possível a existência mesma dos signos, o exame desses meios parece ser um ponto de partida imprescindível para a compreensão das implicações mais propriamente semióticas das imagens, quer dizer das características que elas tem em si mesmas, na sua natureza interna, dos tipos de relações que elas estabelecem com o mundo, ou objetos nelas representados, e dos tipos de recepção que estão aptas a produzir (SANTAELLA, 2001, p. 162).

Para que essas imagens sejam utilizadas como instrumentos de informação e sejam geradoras de conhecimento é necessário, portanto, que o sujeito que irá interagir no ambiente em que tais sinais imagéticos estão inseridos tenha uma percepção apropriada para interpretá-las. Assim, a percepção visual, segundo Aumont (1993, p. 22),

É o processamento em etapas sucessivas, de uma informação que nos chega por intermédio da luz que entra em nossos olhos. Como toda informação, esta é codificada - em um sentido que não é o da semiologia: os códigos são, aqui, regras de transformação naturais (nem arbitrárias, nem convencionais) que determinam a atividade nervosa em função da informação contida na luz. Falar da codificação da informação visual significa, pois, que nosso sistema visual é capaz de localizar e de interpretar certas regularidades nos fenômenos luminosos que atingem nossos olhos.

No tópico seguinte nos basearemos nos aspectos da imagem para assim podermos tecer uma relação do conceito do quali-signo icônico com as qualidades sintáticas da imagem (cor, forma, linha, ponto, volume, luz etc.), a qual a autora Donis A. Dondis (2003) classifica como sintaxe da linguagem visual em seu estudo da forma, mas sem, no entanto, ignorar o lado indicial da imagem, pois, nem todo ícone é necessariamente uma imagem. Dessa forma, na teoria de Peirce, pode-se observar uma distinção muito nítida entre ícones próprios e sin-signos icônicos (ou hipoícones):

[...] um signo pode ser icônico, isso é, pode representar seu objeto principalmente através de sua similaridade, não importa qual seja seu modo de ser. Se o que se quer é um substantivo, um representâmen icônico pode ser denominado de hipoícone 
(PEIRCE, 2003, p. 64).

Feita essas considerações, pode-se discutir como as relações estabelecidas entre o ícone e as formas não-representativas da imagem podem servir como instrumental para análise da linguagem imagética

De acordo com Santaella (2010, p. 86), são três as fases da experiência fenomenológica, sendo a primeira abrir-se os poros do nosso olhar para $o$ sensível, para impregnarmos das cores, linhas, superfícies, formas, luzes. Ou seja, a autora nos diz tudo que diz respeito às qualidades, a exemplo de uma pintura, seu (quali-signo).

A segunda fase dessa experiência seria observarmos atentamente a situação comunicativa que a pintura nos coloca. Esse segundo fundamento do signo denomina-se (sin-signo) e traz a obra em seu caráter existencial. Tem-se aí a realidade da obra enquanto obra (meio físico). Importantíssimo nesse momento é nos darmos conta de que não estamos, de fato, diante da obra original, mas de uma reprodução da obra. Dessa forma, segundo a mesma autora, um sin-signo quadro/obra apresenta quali-signos que são diferentes dos quali-signos de um sin-signo reprodução. Quando o suporte de uma obra se modifica, mesmo se tratando de uma reprodução, suas qualidades (quali-signo) necessariamente se modificam também. E por último a terceira fase da experiência que diz respeito à interpretação.

Na face da significação, a análise semiótica nos permite explorar 0 interior das mensagens em seus três aspectos. $O$ primeiro deles diz respeito às qualidades e sensorialidade de suas propriedades internas, como por exemplo, na linguagem visual, as cores, linhas formas, volumes, movimento, luz etc. O segundo aspecto diz respeito à mensagem na sua particularidade, no seu aqui e agora em um determinado contexto. O terceiro aspecto se refere àquilo que a mensagem tem de geral, convencional, cultural (SANTAELLA, 2010, p. 60).

Segundo a professora de comunicação da Boston University School of Communication, Donis A. Dondis (2003, p. 31) “[...] o processo de composição é o passo mais crucial na solução dos problemas visuais [...]. Os resultados das decisões compositivas determinam o objetivo e o significado da manifestação visual e tem fortes implicações com relação ao que é recebido pelo espectador". 
Figura 1 - Estratégias de comunicação

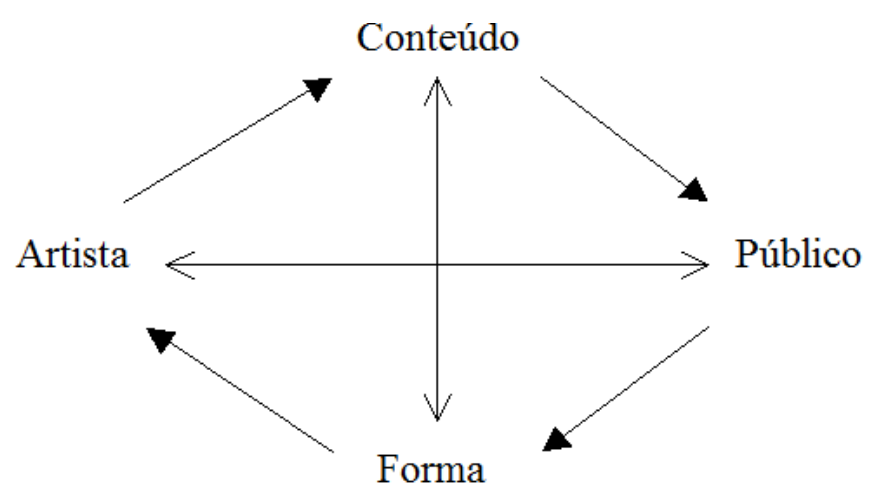

Fonte: Adaptação de Dondis (2003 p. 132).

A linguagem imagética, segundo Oliveira (2004, p. 116), "[...] se constrói a partir de uma peculiar semiose que se estabelecem entre os dois planos constituintes de sua estruturação: o plano da expressão e o plano do conteúdo." No entanto, esses planos não mantêm uma relação arbitrária e nem é centrado em um conjunto de normas, mas ambos têm por finalidade "representar". "A representação é o fenômeno mais geral, o que permite ao espectador ver "por delegação" uma realidade ausente, que the é oferecida sob a forma de um substituto" (AUMONT, 1993, p. 105).

Dessa forma, "[...] a Semiótica fornece métodos de descrição da pintura, na mesma medida em que ela nos fornece meios para melhor apreciá-la - o que já é aproximar-se esteticamente dela" (OLIVEIRA, 2004, p. 115). Contudo, imagem em que se expressa à representação gráfica é distinta da imagem figurativa como cartazes, fotografias, obras de arte e publicidade, cujo conteúdo encontra-se no campo da polissemia, isto é, permite vários significados (BERTIN, 1988; GOMES et al., 2012; LIMA, 2012).

Seguindo as estruturas sintáticas que configuram uma obra pictórica referida por Donis A. Dondis (2003): todos os objetos no mundo, os quais servem de fonte de comunicação visual têm como base estrutural elementos básicos ou a fusão entre eles na base de suas mensagens visuais. O que a Luz nos revela é a substância através da qual o homem configura e imagina aquilo que conhece e identifica no meio ambiente. Isto é, todos os elementos visuais que dominam qualquer manifestação visual, e que é determinado pela natureza daquilo que está sendo concebido. Ou, no caso da própria natureza, daquilo que existe nela: ponto, 
linha, a forma, a direção, o tom, a cor, a textura, a dimensão, a escala e o movimento, os quais são definidos como:

[...] a fonte compositiva de todo tipo de materiais e mensagens visuais, além de objetos e experiências: o ponto, a unidade visual mínima, o indicador e marcador de espaço; a linha, o articulador fluido e incansável da forma, seja na soltura vacilante do esboço seja na rigidez de um projeto técnico; a forma, as formas básicas, o círculo, o quadrado, o triângulo e todas as suas infinitas variações, combinações, permutações de planos e dimensões; a direção, o impulso de movimento que incorpora e reflete o caráter das formas básicas, circulares, diagonais, perpendiculares; o tom, a presença ou a ausência de luz, através da qual enxergamos; a cor, a contraparte do tom com o acréscimo do componente cromático, o elemento visual mais expressivo e emocional; a textura, óptica ou tátil, o caráter de superfície dos materiais visuais; a escala ou proporção, a medida e o tamanho relativos; a dimensão e o movimento, ambos implícitos e expressos com a mesma frequência. (DONDIS, 1997, p. 23).

Dessa forma, o ponto é a unidade de comunicação visual mais simples e irredutivelmente mínima.

Figura 2 - Ponto

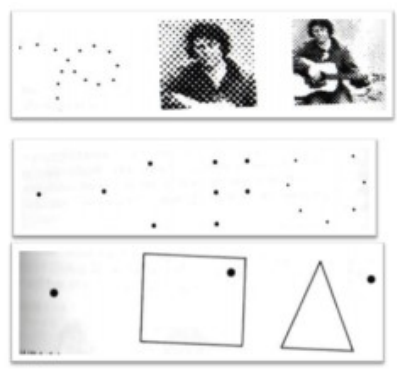

Fonte: Adaptação de Dondis (2003, p. 53-54)

Quando os pontos estão tão próximos entre si, que se torna impossível identificá-los individualmente, aumenta a sensação de direção, e a cadeia de pontos se transforma em outro elemento visual distintivo: a linha, ou também definida como um ponto em movimento.

Figura 3 - Linha

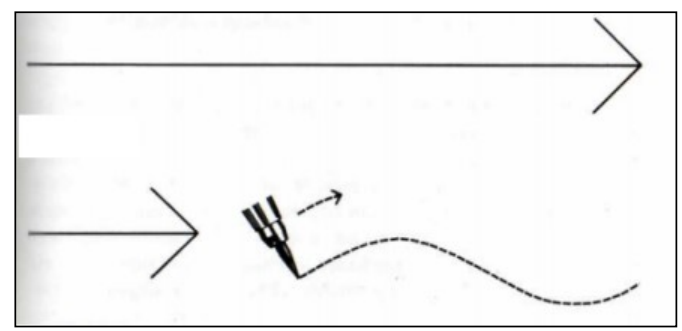

Fonte: Adaptação de Dondis (2003, p. 55) 
A linha descreve uma forma. Na linguagem das artes visuais, a linha articula a complexidade da forma. Existe três formas básicas: o círculo, o quadrado e o triângulo.

Figura 4 - Forma

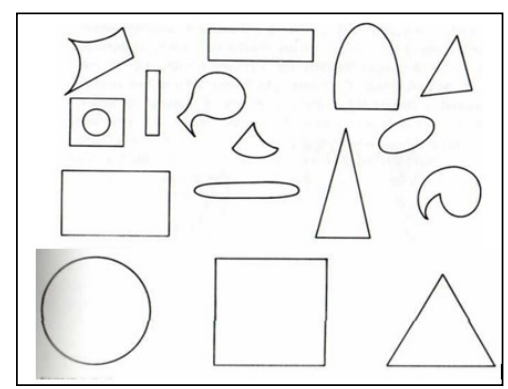

Fonte: Adaptação de Dondis (2003, p. 57-59).

Todas as formas básicas expressam três direções visuais básicas e significativas: o quadrado a horizontal e a vertical; o triângulo, a diagonal; o círculo, a curva. Cada uma das direções visuais tem um forte significado associativo e é um valioso instrumento para criação de mensagens visuais.

Figura 5 - Direção

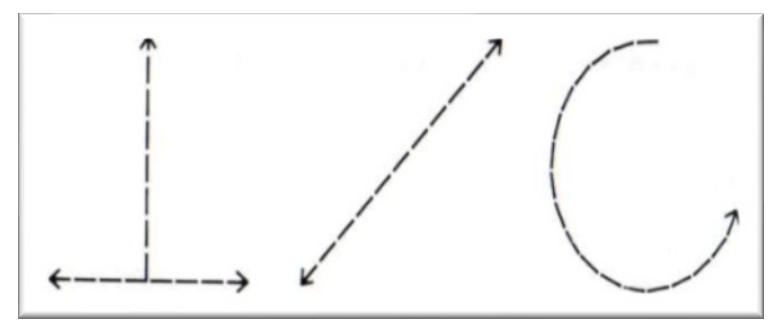

Fonte: Adaptação de Dondis (2003, p. 59).

O tom é a claridade ou a obscuridade de qualquer coisa vista.

Figura 6 - Tom

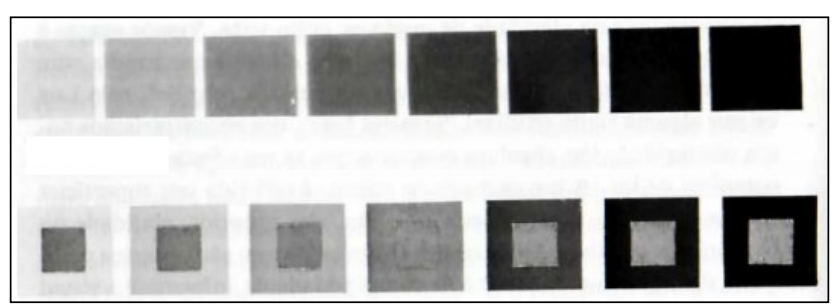

Fonte: Adaptação de Dondis (2003, p. 62)

A cor constitui uma fonte inestimável para a comunicação visual, e é medida através de matizes e escalas cromáticas. 
Figura 7 - Cor

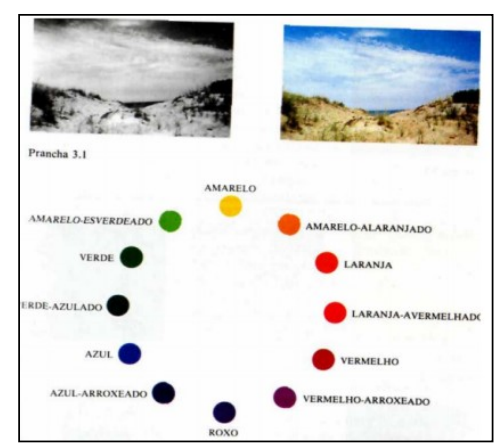

Fonte: Adaptação de Dondis (2003, p. 67).

Apropriando-se da análise do ícone e dos elementos formais compositivos da imagem, a orientação agora é para que inicie seu trabalho pela observação dos aspectos qualitativos da figura (quali-signo icônico), "[...] trata-se de atentar para aquilo que a figura tem de primeiro, suas qualidades" (SANTAELLA, NÖTH, 2001, p. 228). Neste sentido, utilizamos a imagem fotográfica de uma igreja barroca e, buscamos apreender primeiramente suas qualidades elementares.

Figura 8 - Elementos básicos da sintaxe visual

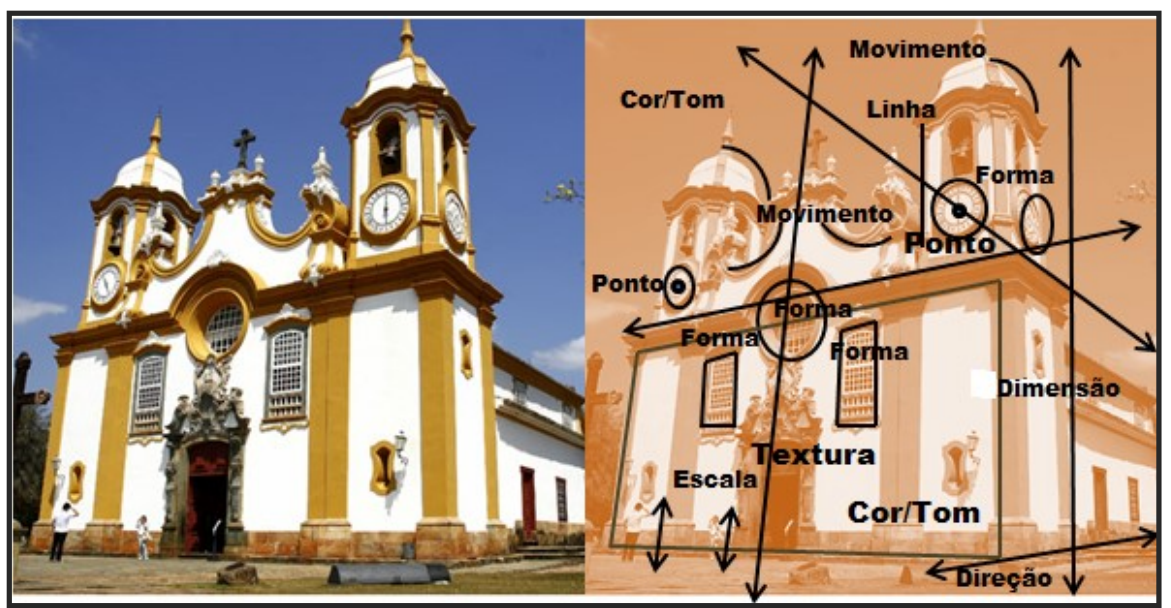

Fonte: Autor.

Utilizamos o exemplo acima para ilustrar como expressamos e recebemos mensagens visuais e os níveis as quais as utilizamos. - o Representacional, ou seja, tudo aquilo que vemos e identificamos com base no meio ambiente e na experiência; o Abstrato, ou seja, a qualidade sinestésica de um fato visual reduzido a seus componentes visuais básicos e elementares, enfatizando os meios mais diretos, emocionais e mesmo primitivos da criação de mensagens. E por último, seu aspecto indicial, pois quando se traz a imagem de uma 
fotografia, já é começar a tratar dos índices, pois a imagem que está na foto tem o poder de indicar exatamente aquela igreja, singular na sua existência.

\section{CONSIDERAÇÕES FINAIS}

A todo momento estamos utilizando nossa cognição para a percepção de informações expostas em mensagens visuais. E também construímos mensagens sígnicas através de uma variedade de linguagens, códigos e sinais que facilitam a nossa comunicação direta ou indiretamente.

Neste sentido, utilizamos como embasamento teórico para este ensaio o uso da Semiótica de Charles Sander Pierce, da Semiótica aplicada de Lucia Santaella e dos fundamentos sintáticos do alfabetismo visual de Donis A. Dondis, como forma de traçarmos uma relação entre os conceitos utilizados por esses autores e aplicarmos no que vimos e significamos o nosso redor.

Concluímos que a comunicação visual, mais especificamente atrelada à signos visuais, está inteiramente relacionada em seus aspectos sintáticos e semânticos com o estudo da Semiótica. Na medida em que ambas trabalham com signos comunicacionais.

E a imagem, fazendo parte da primeira primeiridade, sendo classificada como um quali-signo icônico, ou seja, responsável por estabelecer uma relação de semelhança com seu objeto puramente no nível da aparência, nos traz características elementares da comunicação visual que servem como forma mínima de informação as quais são imprescindíveis para o uso facilitador de conhecimento e alfabetismo visual.

\section{REFERÊNCIAS}

AUMONT, J. A imagem. Campinas: Papirus, 1993.

BARRETO, A. A. Uma quase história da Ciência da Informação.

DataGramaZero, Rio de Janeiro, v. 9, n. 2, abr. 2008. Disponível em: http://dgz.org.br/ago07/Ind_com.htm. Acesso em: 28 ago. 2011.

BERTIN, J. Ver ou ler. São Paulo: AGB, 1988. 
DONDIS, D. A. A sintaxe da linguagem visual. Tradução de Jefferson Luiz Camargo. São Paulo: Martins Fontes, 2003.

GOMES, C. S. dos N.; LIMA, J. J. T.; LIMER, M. E. da C.; MARQUES, R.; FEITOSA, S. Semiologia gráfica e a representação gráfica. Revista Eletrônica Don Domênico, v. 1, n. 5, 2012. Disponível em:

http://faculdadedondomenico.edu.br/novo/revista_don/artigos5edicao/5ed5.pdf. Acesso em: 10 fev. 2016.

HASELAGER, W. F. G. O mal estar do representacionismo: sete dores de cabeça da ciência cognitiva. Tradução Mariana Claudia Broens. In: FERREIRA, A.; GONZALEZ, M. E. Q.; COELHO, J. G. (Org.). Encontro com as Ciências Cognitivas. São Paulo: Cultura Acadêmica, 2004, p. 105-120.

LIMA, F. R. B. Imagem e tecnologia: webmuseu de arte. 2012. $126 \mathrm{f}$. Dissertação (Mestrado em Ciência da Informação) - Universidade Estadual Paulista Júlio de Mesquita Filho, Faculdade de Filosofia e Ciências, Marília, 2012. Disponível em: http://www.marilia.unesp.br/Home/PosGraduacao/Cienciadalnformacao/Dissertacoes/Lima_F_R_B_mestrado_C_I_20 12.pdf. Acesso em: 12 jan. 2015.

LOCKE, J. Ensaio acerca do entendimento humano. São Paulo: Nova Cultura, 1988.

NÖTH, W. Panorama da semiótica: de Platão a Peirce. 4. ed. São Paulo: Annablume, 2008.

OLIVEIRA, A. C. As semioses pictóricas. In: OLIVEIRA, A. C. (Org.). Semiótica plástica. São Paulo: Hacker, 2004. p. 116-158.

OLIVEIRA, S. L. Tratado de metodologia científica: projetos de pesquisas, TGI, TCC, monografias, dissertações e teses. 2. ed. São Paulo: Pioneira, 1997.

PEIRCE, C. S. Collected papers. Hartshorne, Weiss, and Burks (Ed.), 8 vols. Cambridge, Mass.: Harvard University Press, 1931-1958.

PEIRCE, C. S. Semiótica. Tradução de José Teixeira Coelho Netto. São Paulo: Perspectiva, 1990.

PEIRCE, C. S. Semiótica. 3. ed. São Paulo: Perspectiva, 2003.

PLAZA, J. As imagens de terceira geração, tecno-poéticas. In: PARENTE, A. (Org.). Imagem máquina: a era das tecnologias do virtual. Rio de Janeiro: Ed. 34, 1993. p. 72-88.

SANTAELLA, L. O que é Semiótica. São Paulo: Brasiliense, 1983.

SANTAELLA, L. Matrizes da linguagem e pensamento: sonora, visual, verbal. São Paulo: lluminuras/FAPESP, 2001. 
SANTAELLA, L.; NOTH, W. Imagem: cognição, semiótica e mídia. São Paulo: lluminuras, 2001. $193 \mathrm{p}$.

SANTAELLA, L. Semiótica Aplicada. São Paulo: Cengage Learning, 2010.

SILVEIRA, L. F. B. Curso de Semiótica Geral. São Paulo: Quartier Latin, 2007.

\title{
THE ICONIC ASPECT OF VISUAL LANGUAGE
}

\begin{abstract}
Introduction: The perception of information in imagistic signs represented in different forms and media, such as: the photographs, paintings and diagrams, are full of implicit and explicit information. A photograph, for example, is an object, person or place existing, or any historical moment, while containing physical information of its own materiality. Objective: Describe the relationship between the Semiotics of Charles Sanders Peirce and study of form, used in the book 'Syntax of Visual Language'. Methods: The study is of theoretical character, descriptive and exploratory level and was based on the qualitative systematic observation of the literature collected on the theme of Charles Sanders Peirce Semiotics. Results: The study shows the concept of icon and its variables as well, the relation of the iconic sign with the study of the visual elements. Conclusions: The visual communication, more specifically linked to the imagistic language, make relationship to its syntactical aspects and semantic with the study of Semiotics. Visual literacy is of paramount importance as a facilitating method for extracting sign information contained in visual syntaxes, more specifically in images.
\end{abstract}

Descriptors: A Primer of Visual Literacy. Image syntax. Icon. Semiotics. Peirce.

\section{EL ASPECTO ICÓNICO DEL LENGUAJE VISUAL}

\begin{abstract}
RESUMEN
Introducción: La percepción de las informaciones en los signos de imágenes, representadas en diferentes formatos y soportes, entre ellos: las fotografías, pinturas y diagramas, contienen múltiples informaciones implícitas y explícitas. Una fotografía, por ejemplo, representa un objeto, persona o lugar existente, o cualquier momento histórico, al mismo tiempo que contiene informaciones físicas de su propia estructura. Objetivo: Describir la relación entre la Semiótica de Charles Sanders Peirce y el estudio de la forma, utilizada en el libro 'Sintaxis del lenguaje visual'. Metodología: El estudio es de carácter teórico, de nivel descriptivo y exploratorio basado en la observación sistemática cualitativa de la bibliografía recopilada en la temática de la Semiótica de Charles Sanders Peirce. Resultados: El estudio muestra también el concepto de icono y sus variables, la relación del signo icónico con el estudio de los elementos visuales. Conclusiones: La comunicación visual, especialmente la vinculada al lenguaje de las imágenes, se relaciona en sus aspectos sintácticos y semánticos con el estudio de la Semiótica. Es de suma importancia el alfabetismo visual como un método facilitador de extracción de informaciones sígnicas contenidas en las sintaxis visual, más especificamente en las imágenes.
\end{abstract}


Descriptores: Principios del alfabetismo visual. Sintaxis de la imagen. Icono. Semiótica. 